\title{
Applicability of the ISO 17100:2015 Quality Standard in Designing a Training Program for Future Medical Translators: The Case of Turkey
}

\section{Svetlana KARABIYIK*}

\begin{abstract}
Affordable health care overseas and the huge development of medical science, practice and technology create a constant demand for competent medical translators, the profile of whom is full of prerequisites. As mistranslation of medical texts can lead to serious clinical or financial consequences, there is no doubt that medical translations which are produced in good quality are in high demand. Moreover, time pressure and budget limits are inevitable concerns for both the healthcare and translation industries due to rapid developments and globalization issues. Therefore, there is demand for competent medical translators who can not only show an excellent usage of languages of medicine and demonstrate strong translation skills while rendering medical texts but also produce good-quality medical translations within set deadline and cost. Hence, the question, how today's potential medical translators should be trained, needs to be answered. Drawing on such a requirement, the aim of this paper is to explore the applicability of the ISO 17100:2015 Quality Standard in designing a training program for future medical translators with a focus on the competences to be developed.
\end{abstract}

Keywords: medical translation; translation competence; training medical translators; skopos theory; ISO 17100:2015

\section{Introduction}

The aim of this article $^{1}$ is to pursue the way that will lead to the answers to the following questions: How should potential medical translators be trained? Which essential courses should be provided? With this aim, first of all, the concept of translation competence will be explored in detail with a focus on its impact on such profession as a medical translator. In the first section, a theoretical overview of translation competence will be presented. This part will be followed by the analysis of the translations of authentic examples, taken mainly from one of the medical genres as 'discharge summary,' which will be conducted in the scope of Skopos Theory and the ISO 17100:2015 International Quality Standard (requirements for translation services). The main emphasis will be on the professional competences of

\footnotetext{
${ }^{*}$ Medical translator and editor.

E-mail: svet17@hotmail.com; ORCID ID: https://orcid.org/0000-0001-5640-4563.

(Received 4 February 2019; accepted 17 June 2019)

${ }^{1}$ Produced from the author's master's thesis (Filatova 2017) submitted at Istanbul 29 May1s University.
} 
transLogos 2019 Vol 2 Issue 1

Karabiyı, Svetlana, pp. 1-18

Applicability of the ISO 17100:2015 Quality

trans Dogos

A Translation Studies Journal

Standard in Designing a Training Program for

Future Medical Translators: The Case of Turkey

(C) Diye Global Communications diye.com.tr|diye@diye.com.tr

translators which dramatically affect the quality of translations and the time spent on translations. In this regard, the applicability of the six professional competences of translators, which are stated in the ISO 17100:2015 International Quality Standard as the necessity that translation industry requires nowadays, will be examined in the scope of authentic examples taken mainly from different discharge summaries.

\section{Theoretical Overview of Translation Competence}

Before discussing translation competence, the notion of 'competence' should be clarified first:

Competence is the ability of an individual to do a job properly. ... Some scholars see "competence" as a combination of practical and theoretical knowledge, cognitive skills, behavior and values used to improve performance; or as the state or quality of being adequately or well qualified, having the ability to perform a specific role. ${ }^{2}$

In this regard, competence is not just one quality. It serves as a route, which requires certain knowledge and skills, for better performing a specific job. Being competent in one domain means that one is in a state of being able to perform (no more, no less) the job. Thus, if one is a competent translator, $\mathrm{s} / \mathrm{he}$ is trusted that $\mathrm{s} / \mathrm{he}$ can translate properly.

What translation competence is and how it should be developed have been described by translation scholars (see, e.g. Toury 1995, Fraser 2000, Neubert 2000, Presas 2000, Pym 2003 ) in various ways. However, they all commonly point out that an individual who is fluent in a foreign language is not necessarily a competent translator. For example, in his article Pym (2003, 485-6) quoted a set of extraordinary descriptions about what translation competence is.

Bell (1991) describes translator competence as a huge summation: target-language knowledge, text-type knowledge, source-language knowledge, subject area ("realworld") knowledge, contrastive knowledge, then decoding and encoding skills summarized as "communicative competence" (covering grammar, sociolinguistics and discourse). Virtually everything that any kind of linguistics wanted to talk about was tossed into the soup. . . . Neubert $(1994,412)$ offers "language competence," "subject competence" and "transfer competence" as the three main components. . . . Hewson (1995) adds something called "cultural and professional elements" (108), where the "professional" part refers to "remuneration [. . . ] access to and use of proper dictionaries and data banks, access to equivalent material in the second language,

\footnotetext{
2 “What is Competence," accessed May 25, 2019, https://www.igi-global.com/dictionary/conceptualframework-assessment-higher-education/4804.
} 
transLogos 2019 Vol 2 Issue 1

Karabiyık, Svetlana, pp. 1-18

Applicability of the ISO 17100:2015 Quality

trans Dogos

A Translation Studies Journa

Standard in Designing a Training Program for

Future Medical Translators: The Case of Turkey

(C) Diye Global Communications diye.com.tr $\mid$ diye@diye.com.tr

practical knowledge of word-processors and peripherals, and so on" (ibid.; original ellipsis). . . . Kautz $(2000,20)$ takes a slightly different approach, recognizing that translators need knowledge of two languages, world and field knowledge, translation theories and methods. . . . Mayoral $(2001,109)$ insists on components including "common sense (above all), curiosity, ability to communicate, capacity for selfcriticism, meticulousness, ability to synthesize, etc." Anything else? In Douglas Robinson's Becoming a Translator (1997) we find serious attention to the real-world necessities of good typing speeds, Internet discussion groups, and working with a computer. ...

Furthermore, certain research groups have tried to describe the notion of translation competence and the definitions proposed by the PACTE research group ${ }^{3}$ and EMT expert group ${ }^{4}$ deserve mentioning.

According to PACTE, translation competence is expert knowledge needed to translate and it is made up of a system of sub-competences (language sub-competence in two languages; extra-linguistic sub-competence; instrumental/professional sub-competence; psycho-physiological sub-competence; transfer sub-competence; strategic sub-competence) that are inter-related, hierarchical and that these relationships are subject to variations (see PACTE 2003, 47-48).

EMT expert group defines competence as "the combination of aptitudes, knowledge, behaviour and knowhow necessary to carry out a given task under given conditions. This combination is recognised and legitimised by a responsible authority (institution, expert)" (EMT Expert Group 2009, 3). The group has developed a model of competences of a translator. The model consists of the six interdependent competences including translation service provision competence, language competence, intercultural competence, information mining competence, thematic competence, and technological competence (mastery of tools) (4-7).

Zooming in, describing "translation competence" as a single entity is nearly impossible as, obviously, the task of the translator is quite complex. In this regard, the complexity of translation competence in the scope of medical translation arises from the complexity of

\footnotetext{
${ }^{3}$ PACTE research group (Proceso de Adquisición de la Competencia Traductora y Evaluación - Process in the Acquisition of Translation Competence and Evaluation) was formed in October 1997 at the University of Barcelona (Departament de Traducció i d'Interpretació). Its main goal is to investigate translation competence and its acquisition in written translation in order to improve the teaching of translation.

${ }^{4}$ EMT (European Master's in Translation) Project is funded by the European Commission and its aim is to ensure that the required quality is provided by the translation services to meet the needs of translation industry in multilingual/cultural environment in the European Union.
} 
transLogos 2019 Vol 2 Issue 1

Karabiyık, Svetlana, pp. 1-18

Applicability of the ISO 17100:2015 Quality

trans Dogos

A Translation Studies Journal

Standard in Designing a Training Program for

Future Medical Translators: The Case of Turkey

(C) Diye Global Communications diye.com.tr $\mid$ diye@diye.com.tr

translating medical texts per se, the complexity of which comes from many sides, primarily the language of medicine, lack of knowledge of the subject matter, and insufficient research skills.

To go a step further for the sake of the pursuit of current investigation, the examinations of translations of authentic examples, mainly taken from a medical genre as 'discharge summary,' will be examined in the scope of Skopos Theory (Vermeer 1996) and the ISO 17100:2015 International Quality Standard (requirements for translation services) in what follows. However, before zooming in, the characteristics of the medical genre as discharge summary, and the scope of the ISO 17100:2015 International Quality Standard will be clarified.

\section{A Medical Genre: Discharge Summary}

A discharge summary is one of the very common medical genres which a medical translator may encounter. It is the history of the patient's hospitalization (from admission to discharge) which consists of mandatory and non-mandatory components (they vary from hospital to hospital) including mainly medical records about all diagnostic studies, treatment procedures and surgical treatments (if there are any) that were performed over the course of the patient's stay in the hospital. In addition, a discharge summary may include consultation notes from specialists, control notes, used and prescribed medications, as well as the patient's condition when s/he left the hospital. It can be one page long or a multipage report.

A discharge summary is completed by different physicians and nurses during the patient's stay or being diagnosed or treated in the inpatient or outpatient settings. Therefore, most of the time, the author of the source text is not only one person, which can be a challenge for translators. Meanwhile, it should be pointed out that every hospital in Turkey has its own layout and format of the discharge summary that is standardized and approved by the related hospital. Generally, hospitals in Turkey use their own software programs that enable medical professionals to enter the medical records into specified sections about their patients. The program is organized in such a way that it should be compliant with the national health information standards such as ICD-10 diagnosis classification, ${ }^{5}$ national surgical procedure

\footnotetext{
${ }^{5}$ International Classification of Diseases (ICD)
} 
transLogos 2019 Vol 2 Issue 1

Karabiyık, Svetlana, pp. 1-18

Applicability of the ISO 17100:2015 Quality

trans Dogos

A Translation Studies Journal

Standard in Designing a Training Program for

Future Medical Translators: The Case of Turkey

(C) Diye Global Communications diye.com.tr|diye@diye.com.tr

coding, etc. The discharge summary of each patient is electronically stored and can be accessed by all medical professionals who are involved in the patient's service.

The main purpose of the discharge summary is to provide the information to the patient's general physician about his/her hospital visit/stay. Generally, it is given to the patient before $\mathrm{s} / \mathrm{he}$ leaves the hospital. Most of the time, the English translations of discharge summaries are provided to the international patients so that they have an opportunity to inform their physicians (abroad) about what has been done during their hospital course. In addition, the discharge summary is also used for insurance claims, $\mathrm{SGK}^{6}$ or for consulates which pay for the patients' hospital expenses.

A discharge summary includes technical terminology, medical argot, slang and gibberish. Meanwhile, shortness (using short lexical and syntactic forms, acronyms, redundancy, abbreviations, consecutive noun phrases, etc.) is the main characteristics of the language used in the discharge summary. It helps medical professionals to render the information quickly and efficiently (e.g., "kc" — karaciğer [liver]; "ac" — akciğer [lung]; "bb" — böbrek [kidney]; "c/o" — complaint of). Sometimes whole sentences are reduced to a couple of initial letters or doctors do not have enough time to write notes clearly. Moreover, as the author of the present paper, I have observed that sometimes lay terms of patients or incompetent interpreters get into the physician's records, mainly in the section "Hastalık Öyküsü” (History of Present Illness) which is one of the sub-genres of the discharge summary. Therefore, they may sound odd and may be problematic in terms of the intended meaning if, for example, an anatomic term was inaccurately used.

Needless to say, competently done translation of the discharge summary is vital for the patients as it helps them to receive the best and suitable care when they need it. As a discharge summary is to be given to the patient before s/he leaves the hospital, there is a high demand not only for an adequately done translation but also for doing such translation in the shortest possible period of time. In this regard, a medical translator must have the required level of translation competence to accomplish these demands. Therefore, a medical translator is required to be aware of basic specifics and common problems which such a medical genre as a discharge summary includes and know how to tackle them in order to produce better medical

\footnotetext{
${ }^{6}$ SSI (Social Security Institution - Turkish National Health System)
} 
transLogos 2019 Vol 2 Issue 1

Karabiyık, Svetlana, pp. 1-18

Applicability of the ISO 17100:2015 Quality

trans Dogos

A Translation Studies Journal

Standard in Designing a Training Program for

Future Medical Translators: The Case of Turkey

(C) Diye Global Communications diye.com.tr $\mid$ diye@diye.com.tr

translations and meet the deadline. For this specific reason, it might be argued that genrebased teaching approach needs to be applied in a training program on medical translation.

\section{The ISO 17100:2015 International Quality Standard - Requirements for Translation Services}

The word "standard" (noun) is defined in Oxford Dictionary ${ }^{7}$ as "a level of quality or attainment," "a required or agreed level of quality or attainment," "something used as a measure, norm, or model in comparative evaluations." A standard is also "a document, established by consensus and approved by a recognized body." "It provides rules, guidelines or characteristics for activities or their results so that they can be repeated." Thus, standards might be said to aim "the greatest degree of order in a given context". ${ }^{8}$ In this context, it is understood that a standard briefly refers to the 'quality,' 'requirements,' 'measurements,' 'comparisons,' 'results,' 'activities,' and 'approval.'

It goes without saying that different types of industries worldwide have been involved in quality management and improvement programs through the standardization process in order to raise efficiency and compete with other companies of the same sector. Translation services industry is not an exception. In the translation services industry standards play an important role as in any other industry. Therefore, standards specific to the translation services, which cover the translation process per se, the way the translator does the translation, required competences, translation quality, necessity for revision, project management, etc. have been developed.

On the other hand, one certainly would ask "Do we really need standards?" Well, if the quality of the translated material is requested, certainly one would care about quality. However, the definition of "quality" is far from settled and this is precisely the point where standards come into play because they enable the identification of variables that affect the quality of translation and lead us to follow a certain path, a certain set of requirements in order to achieve the translation purpose.

Generally, the ISO 17100:2015 International Quality Standard concerns requirements for the translation process from all relevant aspects which might have a direct effect on the

\footnotetext{
${ }^{7}$ Lexico, s.v. "standard," accessed May 25, 2019, https://en.oxforddictionaries.com/definition/standard.

8 "Standardisation," accessed May 25, 2019,

https://www.gov.uk/government/publications/standardisation/standardisation.
} 
transLogos 2019 Vol 2 Issue 1

Karabiyık, Svetlana, pp. 1-18

Applicability of the ISO 17100:2015 Quality

quality or provision of translation services. It also lays down provisions regarding how core processes must be managed, which minimum qualifications are required, and what resources must be available. Particular attention is paid to the areas of competence of translators, reviewers and proof-readers. The main attention in the present study is paid to the competences related to the translators.

\section{Applicability of the ISO 17100:2015 Quality Standard}

In what follows, the applicability of the six professional competences of translators included in the ISO 17100:2015 International Quality Standard will be explored in the scope of the authentic examples taken from the translations of discharge summaries.

\subsection{Translation Competence}

"Translation competence" is the first competence, stated in the ISO 17100:2015 Quality Standard, a professional translator must possess.

Translation competence: the ability to translate content in accordance with $5.3 .1,{ }^{9}$ including the ability to address the problems of language content comprehension and language content production and the ability to render the target language content in accordance with the client-TSP [translation service provider] agreement and other project specifications. (sec. 3.1.3)

From the above definition, it is understood that the translator is required to be capable of translating texts according to the purpose of the translation project. In this regard, it can be admitted that according to the Standards, the translator as a "bi-cultural expert who knows

\footnotetext{
${ }^{9}$ The Section 5.3.1 of the ISO 17100:2015 Standard states:

"The translator shall translate in accordance with the purpose of the translation project, including the linguistic conventions of the target language and relevant project specifications. Throughout this process, the translator shall provide a service conforming to this International Standard with regards to the following:

a) compliance with specific domain and client terminology and/or any other reference material provided and ensuring terminological consistency during translation;

b) semantic accuracy of the target language content;

c) appropriate syntax, spelling, punctuation, diacritical marks, and other orthographical conventions of the target language;

d) lexical cohesion and phraseology;

e) compliance with any proprietary and/or client style guide (including domain, language register, and language variants);

f) locale and any applicable standards;

g) formatting;

h) target audience and purpose of the target language content.

The translator shall raise any uncertainty as a query with the project manager."
} 
transLogos 2019 Vol 2 Issue 1

Karabiyık, Svetlana, pp. 1-18

Applicability of the ISO 17100:2015 Quality

trans Dogos

A Translation Studies Journal

Standard in Designing a Training Program for

Future Medical Translators: The Case of Turkey

(C) Diye Global Communications diye.com.tr $\mid$ diye@diye.com.tr

how to produce a text for a certain purpose and for target-culture" (Vermeer 1996, 6) is required to produce his/her translations according to the specified skopos. ${ }^{10}$ The example related to the applicability of the requirement related to compliance with the purpose of the translation project or skopos is discussed below.

The following example is an excerpt from the "Operative Note" section of a discharge summary which was written by a plastic surgeon who works in the department of Aesthetic, Plastic \& Reconstructive Surgery.

(ST) . . Batın ile sarıldıktan sonra operasyon sonlandırıldı.

(TT) ... The surgery was terminated after the dressing was applied.

The "Operative Note" section is one of the sub-genres of a discharge summary. Most of the time, the operative note is written for physicians. Translating operative notes is a big challenge for translators because apart from the complexity of the language of surgery per se, shortened forms of words, uncommon abbreviations (sometimes whether it is a Turkish abbreviation or an English abbreviation cannot be identified) and misspelled terms make understanding nearly impossible. Generally, an English translation of a discharge summary is needed if it is requested by an insurance company of a patient or if a patient's native language is other than Turkish. The above example is an excerpt from the "Operative Note" section of a discharge summary of one of the international patients of the hospital where the author of the present study worked a year ago.

The purpose of this operative note is to inform other physicians about what was done. A literal translation of the above statement would be: "The surgery was terminated after dressing with abdomen." However, obviously, there is a problem here since the word 'batın' (abdomen) makes the whole statement sound 'odd.' After the discussion made with the surgeon (writer of the source text), I, as the translator of the source text in question, learned that he actually used the word 'batın' (abdomen) instead of 'batın kompres' (similar to a gauze pad). However, using alone only the first word makes the statement sound 'odd.' It should be pointed out that using only 'batın' for 'batın kompres' in the given operative note is understandable only by plastic surgeons.

\footnotetext{
${ }^{10}$ The word skopos is a Greek word that means 'goal, aim or purpose.' In his discourse, Vermeer uses the word skopos in the meaning of 'aim or purpose of a translation.' In his book, A Skopos Theory of Translation: Some Arguments for and against, he (1996) states that translating is such an action that embraces the purpose and aim, the output of which leads to the target text.
} 
transLogos 2019 Vol 2 Issue 1

Karabiyık, Svetlana, pp. 1-18

Applicability of the ISO 17100:2015 Quality

trans Dogos

A Translation Studies Journal

Standard in Designing a Training Program for

Future Medical Translators: The Case of Turkey

(C) Diye Global Communications diye.com.tr $\mid$ diye@diye.com.tr

Eventually, the surgeon suggested that as an insurance company of the patient needed the English translation of the discharge summary, I could translate the statement by only saying that the surgery was terminated after the dressing was applied. In this regard, according to the surgeon, specifying that a gauze pad was used was unnecessary.

Moreover, it deserves pointing out that a close look at Section 5.3.1 of the Standard reveals that 'translation competence,' in fact, includes the ability to use and apply all other five competences specified in the Standard by taking into consideration the purpose of the translation project or in Vermeer's term, skopos. Bearing the above in mind, one may come to a conclusion that other five competences are the sub-competences of the translation competence. As a result, it has been justified that describing the notion 'translation competence' as a single entity is nearly impossible as, certainly, the task of the translator is quite complex. In this regard, the complexity of translation competence in the scope of medical translation can be further argued to arise from the complexity specific to translating medical texts.

Thus, a competent translator is required not to miss out the functional equivalence of the target text by simply following the conventions of the source text. $\mathrm{S} / \mathrm{he}$ has to be able to translate according to the skopos. Meanwhile, it should also be pointed out that when it comes to the professional competences of translators, Skopos Theory goes parallel with the ISO 17100:2015 Quality Standard. Hence, it is argued that a potential medical translator should study translation theories and learn how to utilize them in practice, especially in justifying his/her translational acts.

\subsection{Linguistic and Textual Competence in the Source Language and the Target Language}

According to the ISO 17100:2015 Quality Standard, translators must have:

\section{Linguistic and textual competence in the source language and the target language} [which is] the ability to understand the source language, fluency in the target language, and general or specialized knowledge of text-type conventions. This linguistic and textual competence includes the ability to apply this knowledge when producing translation or other target language content. (sec. 3.1.3)

Understanding the source language and attaining the fluency of the message in the target text are very important. As international communication among physicians and scientists is now almost entirely in English and there is continued coinage of new terms from 
transLogos 2019 Vol 2 Issue 1

Karabiyık, Svetlana, pp. 1-18

Applicability of the ISO 17100:2015 Quality

trans Dogos

A Translation Studies Journal

Standard in Designing a Training Program for

Future Medical Translators: The Case of Turkey

(C) Diye Global Communications diye.com.tr $\mid$ diye@diye.com.tr

Latin and Greek, studying the specifics of medical English (medical terms, acronyms and abbreviations, stacked noun phrases, argot, and systematized nomenclatures) and understanding the basic rules for building and breaking down the medical terms will help translators of medical texts both to build and translate many different words in a shorter period of time. On the other hand, apart from Greek and Latin, medical English is full of borrowings from modern foreign languages including German, French, Italian, and Arabic. For example, in his book, The Language of Medicine, John H. Dirckx states that borrowings from French outweigh borrowings from German. Therefore, the translator of medical texts has to be aware of the complexity of medical language.

On the other hand, as communication among medical professionals and communication between patient and doctor are still conducted in Turkish in Turkey, mastering the specifics of the Turkish medical language is also important for translators who are going to produce medical translations in Turkish or translate from Turkish. In this respect, a competent medical translator should be aware of the specifics and common problematic aspects of English and Turkish languages of medicine.

Moreover, going beyond the language level, the above-mentioned standard demands that a translator also has to pay attention to text-type conventions that determine which wording has to be used to describe a particular medical situation. In the context of medical translation, each medical genre also has its own text-type conventions. For example, a pathology report ${ }^{11}$ is one of the medical genres a medical translator may encounter during his/her career. It may be quite complex for beginner medical translators to translate due to text-type conventions and very special wordings. Therefore, translating them requires the above-mentioned competences. The following example (taken from a pathology report) will demonstrate how the linguistic and textual competences would help translators in such a complicated and challenging work:

\footnotetext{
11 "A pathology report is a medical report about a piece of tissue, blood, or body organ that has been removed from the body. The specimen is analyzed by a pathologist. He or she writes up a report for the healthcare provider who has either ordered the report or done the procedure. Pathology reports are used by the patient's provider to figure out a diagnosis or treatment plan for a specific health condition or disease." (University of Rochester Medical Center Health Encyclopedia, s.v. "The Pathology Report," accessed May 25, 2019, https://www.urmc.rochester.edu/encyclopedia/content.aspx?contenttypeid=85\&contentid=P00964.)
} 
transLogos 2019 Vol 2 Issue 1

Karabiyık, Svetlana, pp. 1-18

Applicability of the ISO 17100:2015 Quality

trans Dogos

A Translation Studies Journal

Standard in Designing a Training Program for

Future Medical Translators: The Case of Turkey

(C) Diye Global Communications diye.com.tr $\mid$ diye@diye.com.tr

(ST) MAKROSKOBİK BULGULAR

. . . Mukozası kabalaşmalar içermekte olup, duvarı en kalın olduğu yerde $0,3 \mathrm{~cm}$ ölçülmüştür. Takip/Kalan doku: 3/1/V

\section{(TT 1) MICROSCOPIC FINDINGS}

... Mucosa contains coarsening. The wall was measured as $0.3 \mathrm{~cm}$ in the thickest area. Followed/Rest tissue: $3 / 1 / \mathrm{V}$

\section{(TT 2) GROSS EXAMINATION}

... The mucosa has a coarse appearance. The wall is measured as $0.3 \mathrm{~cm}$ in the thickest area. Submitted/Remainder: 3/1/V

How linguistic and textual competences affect the quality of translation in the case of medical communication is clearly seen in the above example. There is a difference in wording and conventions between source and target systems involved. For instance, it is accepted among pathologists that instead of "MICROSCOPIC FINDINGS," "GROSS EXAMINATION" has to be used for the statement "MAKROSKOBİK BULGULAR." Meanwhile, when it comes to tense usage, mostly present tense is used instead of past in the target system. Moreover, "Takip/Kalan doku" has to be translated as "Submitted/Remainder," which is also used by pathologists in the Turkish system. So, the second target text was prepared more competently. In addition, it should be pointed out that a competent translator who translates pathology reports into English is required to know about the College of American Pathologists (CAP) whose standards and guidelines are used by many pathologists to provide uniform reporting. Similar to a technical writer, in order to produce a target text with desired communicative function, translators are required to use not only the source text but also various other sources.

Thus, a competent translator is required to master the English and Turkish languages of medicine and be familiar with the genres of the medical texts with which $\mathrm{s} / \mathrm{he}$ is working for the understandability of the message and not missing out the functional equivalence of the target text by simply following the conventions of the source text.

5.3 Competence in Research, Information Acquisition, and Processing

Having competence in research, information acquisition, and processing is another requirement that is stated in the ISO 17100:2015 Quality Standard. 
transLogos 2019 Vol 2 Issue 1

Karabiyık, Svetlana, pp. 1-18

Applicability of the ISO 17100:2015 Quality

trans Dogos

A Translation Studies Journal

Standard in Designing a Training Program for

Future Medical Translators: The Case of Turkey

(C) Diye Global Communications diye.com.tr|diye@diye.com.tr

Competence in research, information acquisition, and processing: the ability to efficiently acquire the additional linguistic and specialized knowledge necessary to understand the source language content and to produce the target language content. Research competence also requires experience in the use of research tools and the ability to develop suitable strategies for the efficient use of the information sources available. (sec. 3.1.3)

The research competence and ability to reach the right information are also indispensable variables that definitely help translators in producing better medical translations in a shorter time. As medical science consists of many fields including anesthesiology, algology, cardiology, dentistry, endocrinology, gastroenterology, neurology, oncology, urology, etc., a medical translator may deal with texts related to different branches of medicine that consist of special terminology and vernaculars. Obviously, neither a translator nor a medical professional may be a full expert in every subject of medicine. Therefore, a translator has to know how to find out the particular information which is required to craft a competently produced target text.

Although a detailed discussion on how medical translators can master their research skills is not the main focus of the present study, it should be underlined that such a skill is also one of the requirements a professional medical translator is required to possess. Even knowing how to use Google search engine efficiently is very important for translators working in the field. In fact, the Google search engine is a primary tool which translators use every day. There are many search tips and tricks which translators can learn, thereby maximize their search efficiency. For example, by using different Google tabs, e.g. 'Web,' 'Images,' 'Shopping,' a translator may easily find very specific information s/he needs.

In this context, the authentic example below demonstrates how the research competence works when it is needed. The example is an excerpt from an informed consent form ${ }^{12}$ "Revizyon veya Sekonder Rinoplasti" (Revision or Secondary Rhinoplasty) which, as the author of the present study, I was assigned to translate in the shortest time possible. To find some expressions used in the context, I used "Books" tab on the top of Google as a research tool. Eventually, while translating "Bir kişinin cerrahi bir girişimi seçmesi risklerin faydaya kıyasına dayanır" (An individual's choice to undergo a surgical procedure is based

\footnotetext{
12 "Informed consent" is a medical document through which "a patient learns about and understands the purpose, benefits, and potential risks of a medical or surgical intervention, including clinical trials, and then agrees to receive the treatment or participate in the trial." (MedicineNet, s.v. "Informed consent," accessed May 27, 2019, https://www.medicinenet.com/script/main/art.asp?articlekey=22414.)
} 
transLogos 2019 Vol 2 Issue 1

Karabiyık, Svetlana, pp. 1-18

Applicability of the ISO 17100:2015 Quality

trans Dogos

A Translation Studies Journal

Standard in Designing a Training Program for

Future Medical Translators: The Case of Turkey

(C) Diye Global Communications diye.com.tr $\mid$ diye@diye.com.tr

on the comparison of the risk to potential benefit), I found nearly the same consent form written already in English (Hathiram and Khattar 2013).

As a result, by using the matched expressions from the above-mentioned book while crafting the target text, I could easily manage to translate some problematic parts of the consent form in a shorter time. Thus, it might be argued that development of research competence needs to be specifically focused on in a training program to be designed specifically for training medical translators.

\subsection{Cultural Competence}

As languages vary from each other, cultures to which they belong also differ as they have different historical backgrounds with a variety of factors including population movements, social values, religious customs, etc.

According to the ISO 17100:2015 Quality Standard, the translator must possess cultural competence which is the "ability to make use of information on the behavioural standards, up-to-date terminology, value systems, and locale that characterize both source and target language cultures" ( $\sec 3.1 .3)$.

In the specific context of medical translation, translators may also need to deal with the texts which are culturally conditioned. Hence, a medical translator is also required to be aware of the cross-cultural situations when a culturally sensitive translation is required and be competent in dealing with challenges such translation may cause.

How cultural competence may help a translator in crafting the target text can be observed by examining the translation process of the following excerpt from the discharge summary of a patient who was admitted to a hospital in pursuit of treatment:

(ST) Hastalık Öyküsü/Hikayesi Hasta acil servise kusma ve çarpıntı şikayetiyle başvurdu. Dün gittiği partide m, eks ve alkol almıș.

(TT) History of Present Illness The patient was admitted to the Emergency Department with complaints of vomiting and palpitation. He used m, ecs and drank alcohol at a party yesterday.

The above example demonstrates that we are vis-à-vis the implicitly expressed source text that was produced as the response of culturally conditioned perception of the Turkish physician towards the information provided by the patient. Instead of expressing the situation in a sentence such as "He used marihuana, ecstasy and drank alcohol at a party yesterday," 
transLogos 2019 Vol 2 Issue 1

Karabiyık, Svetlana, pp. 1-18

Applicability of the ISO 17100:2015 Quality

A Translation Studies Journal

Standard in Designing a Training Program for

Future Medical Translators: The Case of Turkey

(C) Diye Global Communications diye.com.tr|diye@diye.com.tr

the patient's physician wrote "He used m, ecs and drank alcohol at a party yesterday." The patient is a 20-year-old Turkish man who requested an English translation of his discharge summary because he had to provide it to his international insurance company. Taking into consideration the value systems of the patient, his physician, and community to which they belong, the attitude of the physician might be deemed understandable. As the English translation of the discharge summary goes abroad, there is no problem to write full forms of those words (marihuana and ecstasy). Nevertheless, as the translator of the source text in question, I used the word 'cannabis' instead of 'marihuana' as it also refers to the flower and is widely used in scientific branches. ${ }^{13}$ When it comes to the word 'ecstasy,' I decided to use its abbreviation which is 'XTC' 14 to preserve a little obscurity. Eventually, I translated the sentence "Dün gittiği partide m, eks ve alkol almış" as "He used cannabis, XTC and drank alcohol at a party yesterday."

Drawing on the above specific example, it can be argued that cultural competence in the context of medical translation is crucial and special attention needs to paid to the development of such competence to train medical translators who are aware of cultural differences and who can make translation decisions on the basis of their awareness of cultural difference and diversity.

\subsection{Technical Competence}

Nowadays, technology has dramatically changed the way translators perform their duties and the way the whole translation industry works. Translators use computers, computerassisted translation (CAT) tools, translation memories and glossaries instead of a pen, papers and paper-based resources. As high speed in achieving many tasks is in demand today and work providers are concentrating on high productivity, cost efficiency and competitiveness, translators have to find solutions quickly for completing given tasks faster and at the same time achieve efficiency and satisfaction on the part of the clients. In this regard, it is expected from translators, among other competences, to be competent in technology-related knowledge needed to meet those expectations.

\footnotetext{
${ }^{13}$ Wikipedia, s.v. "Cannabis (drug)," accessed May 28, 2019, https://en.wikipedia.org/wiki/Cannabis_(drug).

${ }^{14}$ Urban Dictionary, s.v. "XCT," accessed May 28, 2019, https://www.urbandictionary.com/define.php?term=xtc.
} 
transLogos 2019 Vol 2 Issue 1

Karabiyık, Svetlana, pp. 1-18

Applicability of the ISO 17100:2015 Quality

A Translation Studies Journal

Standard in Designing a Training Program for

Future Medical Translators: The Case of Turkey

(C) Diye Global Communications diye.com.tr $\mid$ diye@diye.com.tr

Likewise, according to the ISO 17100:2015 Quality Standard, the translator has to possess technical competence which is "the knowledge, abilities, and skills required to perform the technical tasks in the translation process by employing technical resources including the tools and IT systems that support the whole translation process" (sec. 3.1.3).

If a medical translator is given a task to translate a 30 pages long medical document in two hours because a translation memory and glossary are provided by a project manager, completing the task in time may be impossible if the translator does not possess abovementioned 'technical competence.' In this context, the computer-literacy, mainly competence in using the CAT tools software and effective use of terminology are the must in order to survive while meeting the demands of work providers.

\subsection{Domain Competence}

"Domain competence" is the last professional competence of translators, which is stated in the ISO 17100:2015 Quality Standard as "the ability to understand content produced in the source language and to reproduce it in the target language using the appropriate style and terminology" (sec. 3.1.3).

There are many cases when medical practitioners produce texts in such a way that only those who are familiar with the context can understand their texts as illustrated in the following example:

(ST) Muayene Bulguları EK: TİP 3 DÜZENLİ 5,8 MM

LO: 4ANT 1-2 KÇK

RO: 6-7 ANT

(TT) Physical Examination Findings ENDOMETRIAL THICKNESS: 5.8

MM, TYPE 3, REGULAR CONTOURS

LEFT OVARY: 4 ANTRAL FOLLICLES, 1-2 PRENATAL

RIGHT OVARY: 6-7 ANTRAL FOLLICLES

The above example is an excerpt from a discharge summary of a patient who visited a gynecologist for the check-up. In the "Muayene Bulguları" (Physical Examination Findings) section, some phrases and abbreviations which were specified by the gynecologist after the patient had been physically examined can be seen. If a translator has the lack of subject-matter knowledge in the field of Obstetrics and Gynaecology, s/he will not understand any of those abbreviations mentioned in the source text. Of course, s/he can ask the writer of the source 
transLogos 2019 Vol 2 Issue 1

Karabiyık, Svetlana, pp. 1-18

Applicability of the ISO 17100:2015 Quality

trans Dogos

A Translation Studies Journal

Standard in Designing a Training Program for

Future Medical Translators: The Case of Turkey

(C) Diye Global Communications diye.com.tr $\mid$ diye@diye.com.tr

text (subject matter expert) what these abbreviations mean in Turkish. However, it is not always possible. Therefore, subject-matter knowledge eases the translation process and contributes to competently produced translation and it is understood why the private sector today usually looks for translators who are specialized in one particular field, rather than ones who claim that s/he works with all types of texts. Therefore, the ISO 17100:2015 Quality Standard counts the subject-matter knowledge of translators as an important variable that affects the quality of the target text.

To conclude, as working background knowledge of narrow fields allows translators to produce better medical translations, it is argued that developing domain competence might be a focus in a training program in the field of medical translation in order to train translators with the level of subject-matter knowledge required by the translation industry.

\section{Discussion and Conclusion}

As illustrated through the examination of the specific examples throughout the present study, medical texts involve complexity and potential pitfalls with which a medical translator may encounter every day. Moreover, there is demand for competent medical translators who can not only show an excellent usage of languages of medicine and demonstrate strong translation skills while rendering medical texts but also produce good-quality medical translations within set deadline and cost, which has serious repercussions on the training of potential medical translators and hence on the professional competences to be developed in such a training.

Above-presented exploration of the applicability of the six professional competences of translators included in the ISO 17100:2015 International Quality Standard within the framework of Skopos Theory and through the genre-based analysis of authentic translation examples taken from discharge summaries has shown that the specific professional competences in the Standard are highly relevant for the training of medical translators who can meet the demands of the translation industry by producing medical translations in accordance with specific translation skopoi.

Thus, it is argued that the six competences in the Standard are required to be addressed in a training program to be specifically designed to train medical translators and such a training 
transLogos 2019 Vol 2 Issue 1

Karabiyık, Svetlana, pp. 1-18

Applicability of the ISO 17100:2015 Quality

trans Dogos

A Translation Studies Journal

Standard in Designing a Training Program for

Future Medical Translators: The Case of Turkey

(C) Diye Global Communications diye.com.tr|diye@diye.com.tr

program would include specific courses devoted to the development of the specific competences.

One course to be included in the program, in line with the definition of the "translation competence' in the Standard, might be on 'Translation Theory and Practice for Medical Translators,' which would help translation trainees establish links between theory and practice and learn how to utilize theories in practice, especially in justifying their translational acts as expert medical translators. In light of the 'linguistic and textual competence in the source language and the target language,' the second competence of the Standard, courses such as 'English for Medical Purposes' and 'Turkish for Medical Purposes' might be included in the program to help trainees achieve advanced levels of medical English and Turkish languages.

A course on 'Research Skills for Medical Translators' and a course on 'Computer Aided Translation Technology' might be included in line with the third competence of the Standard, the 'competence in research, information acquisition, and processing,' and the 'technical competence' as the fifth competence in order to enable trainees to improve their research and technical competence, which can be argued to be vital considering the demand for high quality medical translations that are both accurate and produced on time. Drawing on the role played by culture in medical practices and in accordance with the 'cultural competence' as the fourth competence in the Standard, a course on 'Medicine and Culture' might be included in the program to familiarize trainees with the cultural differences involved in the two systems engaged in the translation situation and raise their awareness of cultural difference and diversity. Drawing on the sixth competence, the 'domain competence,' courses on 'Medical Translation and its Genres' and 'Medicine for Translators' can be included in the program in order to help trainees achieve the required level of genre-based subject matter knowledge and produce quality medical translation.

As a final remark, it should be underlined that the courses suggested above correspond to the competences which are included in the ISO 17100:2015 International Quality Standard and which are not independent from each other. Thus, special attention is required to be paid to the cross-curricular links for the design of the content of suggested courses, which is a topic of further research. 


\section{References}

Dirckx, John H. 1976. The Language of Medicine: Its Evolution, Structure and Dynamics. Maryland: Harper and Row.

EMT Expert Group. 2009. "Competences for Professional Translators, Experts in Multilingual and Multimedia Communication." European Commission. https://ec.europa.eu/info/sites/info/files/emt_competences_translators_en.pdf.

Filatova, Svetlana. 2017. “Becoming a Medical Translator: Who Are the Experts?" Master's thesis, Istanbul 29 Mayis University.

Fraser, Janet. 2000. “The Broader View: How Freelance Translators Define Translation Competence." In Developing Translation Competence, edited by Christina Schäffner and Adab Beverly, 51-62. Amsterdam: John Benjamins.

Hathiram, Bachi T., and Vicky S. Khattar. 2013. Facial Plastics, Cosmetics and Reconstructive Surgery. Vol. 3 of Atlas of Operative Otorhinolaryngology and Head and Neck Surgery. New Delhi: Jaypee Brothers.

ISO (International Organization for Standardization). 2015. Translation Services $\begin{array}{lllll}\text { Requirements for Translation Services. } & \text { ISO } & 17100 .\end{array}$ http://www.eurocom.at:8080/vmapplicants/docs/Excerpt\%20from\%20ISO_17100_2 015.pdf.

Neubert, Albrecht. 2000. "Competence in Language, in Languages, and in Translation." In Developing Translation Competence, edited by Christina Schäffner and Beverly Adab, 3-18. Amsterdam: John Benjamins.

PACTE. 2003. "Building a Translation Competence Model." In Triangulating Translation: Perspectives in Process Oriented Research, edited by Fabio Alves, 43-66. Amsterdam: John Benjamins.

Presas, Marisa. 2000. "Bilingual Competence and Translation Competence." In Developing Translation Competence, edited by Christina Schäffner and Beverly Adab, 19-31. Amsterdam: John Benjamins.

Pym, Anthony. 2003. "Redefining Translation Competence in an Electronic Age: In Defence of a Minimalist Approach." Meta 48 (4): 481-497. doi: 10.7202/008533ar.

Toury, Gideon. 1995. Descriptive Translation Studies — and Beyond. Amsterdam: John Benjamins.

Vermeer, Hans J. 1996. A Skopos Theory of Translation: Some Arguments for and against. Heidelberg: TEXTconTEXT. 